\title{
ADMINISTRATIVE LAW SYMPOSIUM: QUESTION \& ANSWER WITH PROFESSORS ELLIOTT, STRAUSS, AND SUNSTEIN
}

\author{
KEY: \\ $\mathrm{DP}=$ Dick Pierce, Moderator $\dagger$ \\ $\mathrm{DE}=$ Donald Elliott* \\ PS $=$ Peter Strauss** \\ $\mathrm{CS}=$ Cass Sunstein $* * *$
}

DP: Before you get your chance at questions, Peter said enough to provoke a request from Cass Sunstein for three minutes of rebuttal time, which I have granted.

CS: I was uncharacteristically cautious, wasn't I? The three major cases that divide contemporary ideas about adiministrative law have to be Chevron, ${ }^{1}$ State Farm, ${ }^{2}$ and Heckler v. Chaney, ${ }^{3}$ right? Chevron on deference to agency determinations of law, State Farm on the hard look doctrine, Heckler v. Chaney against agency inaction. I think Chevron's analysis was badly off, State Farm was basically right, and I think Heckler v. Chaney points in the wrong direction in drawing this sharp distinction between action and inaction. In understanding why I think that, I thimk Peter is exactly right in pointing to the systemic ex ante effects of judicial review.

Most of the real world is affected by these three cases not because of "bubbles" and passive restraints and drugs being injected and people are going to be executed as a result-those are important, yes, but administrative law now is done day to day in the shadow of these three cases. That's the systemic ex ante effect and that is huge. Now, Don's data are extreinely interesting and important. When thinking about the impact of judicial review, one wants to think also about the systemic ex ante effect.

$\dagger$ George W. Hutchinson Professor of Law, Southern Methodist University. B.S. 1965, Lehigh University; J.D. 1972, University of Virginia.

* Professor of Law, Yale Law School.

** Betts Professor of Law, Columbia University School of Law.

*** Karl N. Llewellyn Professor of Jurisprndence, Law School and Department of Political Science, University of Chicago.

1. Chevron, U.S.A., Inc. v. NRDC, 467 U.S. 837 (1984).

2. Motor Vehicle Mfrs. Ass'n v. State Farm Mut. Auto. Ins. Co., 463 U.S. 29 (1983).

3. Heckler v. Chaney, 470 U.S. 821 (1985). 
One need look no further than the Mashaw and Melnick studies, ${ }^{4}$ which showed that the allocation of authority internal to the agency is dramatically affected by judicial determinations of this sort. In the OSHA and EPA cases, the most important thing is not whether the remand comes up the same way next time; it's that it has a ripple effect on what the agency does every day afterwards. The decision will still be political; most of these cases will never get to court, but their political character will be affected very dramatically by the existence of the previous case. The OSHA decision in Benzenes had effect not only on what OSHA does, but on what the EPA does and on what the FDA does. A lot of federal regulatory policy is affected by this case, and it has nothing to do with ex post litigation at all. I think in that respect, Peter hasn't taken far enough his initial correct insight about the systemic effect of judicial review.

Now, one wants to ask, is this a good systemic effect or a bad one? That's a complicated issue. The two things one wants to think about are legahty and the real world. There is a lot to be said for the claim that both legality and the real world are made better, are better served, by aggressive judicial review of administrative action.

One very quick way to make this point is to look at what's happened under President Reagan's Executive Order No. 12,291.6 That is not quite a substitution of pohtical controls for legal controls; that's complementary and not exclusive. The Executive Order is done in the shadow of the hard look doctrine. You can't read the annual regulatory program of the President without seeing the omnipresence of both legality requirements and rationality requirements. If you talk to anyone involved early on or today in the OMB process, their eyes are on the statute books and on rationality, and that owes a whole lot to the hard look doctrine and to what preceded Chevron. The reason I have enthusiasm for State Farm and skepticism about Chevron is because what those cases, if rightly decided, will do, is to ensure that you get the analysis first and the conclusion second, rather than vice-versa. My fear is that the abandonment of aggressive judicial review-the continuation of Chevron, which says that those limited by authority judge the scope of the limitation, an idea extraordinarily foreign to our traditions-and abandonment of State Farm, the consequence of those things simultaneously will be to permit conclu-

4. Mashaw \& Harfst, Regulation and Legal Culture: The Case of Motor Vehicle Safety, 4 Yale J. ON Reg. 257 (1987); R. Melnick, Regulation and the Courts: The Case of the Clean AIR ACT 379.83 (1983).

5. Industrial Union Dep't, AFL-CIO v. American Petroleum Inst., 448 U.S. 607 (1980).

6. Exec. Order No. 12,291, 44 C.F.R. 1 (1988), reprinted in 5 U.S.C. $\S 601$ (1982). 
sion first and analysis second, which serves neither legality nor the real world very well.

DE: I like Chevron, I don't like State Farm, and I tend not to like Heckler. I think the key difference between Cass and me in this area is that I tend to incline more toward Peter's view of preferring alternatives to courts as reviewing institutions. I don't think the executive order process exhausts the potential creativity for devising a lot of other alternatives to court to perform some of these functions. But I would take issue with the assertion that we know that the effects of judicial review on the administrative process and on the internal deliberations within agencies are huge. I know about some of these articles that give Bill Pedersen's ${ }^{7}$ and Shep Melnick's $s^{8}$ and I think to a lesser extent Jerry Mashaw's ${ }^{9}$ view-I think I read Mashaw's study very differently, Cass. I see [it] as being essentially a political process that drives that shift, in which the courts and the visibility that courts bring to particular proceedings play a role, but I think it's a misreading of what's really going on in both Melnick's and Mashaw's work to suggest that the courts are producing this effect. I think it's nuch nore of a total pohitical context within which the regulatory action is taking place.

PS: I agree with a good deal of what Cass Sunstein has said, but want to call attention to an unstated premise in his analysis. To the extent his arguinent was that legality and the courts are particularly important in keeping the President's pohtical controls under control, I would agree. $\mathrm{He}$ and I, as you may know, cooperated in the past on a study ainied in that direction. ${ }^{10}$ But keeping the President an honest political broker is a different proposition fron taking over supervision of political outcomes at the agency level, and that's where I tend to be cautious. In part this is because if we are going to be candid we have to measure our ideal of an apolitical judiciary against the reality of sonie politicization. One of the realities that you'll find in Dick Pierce's analysis in the Duke Law Journal ${ }^{11}$ is that the D.C. Circuit opinions are not only activist, and thus dismissive of agency outconies, but also very readily explamed on the basis of politics. They are sharply divided along political lines. From the very outset, when the great Chief Justice outlived his party for more than three decades, we have known that judges may be only our longest lived

7. Pedersen, Formal Records and Informal Rulemaking, 85 YALE L.J. 38 (1975).

8. See S. MeLnick, supra note 4.

9. See J. MASHAW, supra note 4.

10. Strauss \& Sunstein, The Role of the President and OMB in Informal Rulemaking, 38 ADMIN. L. REV. 181 (1986).

11. Pierce, Two Problems in Administrative Law: Political Polarity on the District of Columbia Circuit and Judicial Deterrence of Agency Rulemaking, 1988 DukE L.J. 300, 303-13. 
and least responsible politicians. One of the situations that faces the country today and may be endemic for our future is that we have a Republican presidency and a Republican judiciary lined up against a Democratic Congress. That may suggest that legality is too simple an expression for understanding judicial behavior. Might one argue, for example, that an allegiance between President and judiciary against Congress provides some means for understanding the judiciary's increasing taste for plain meaning approaches to statutory interpretation? ${ }^{12}$ To the extent that we imagine judicial review as delivering political services, rather than defending individual rights, judges' political characteristics become perliaps especially problematic. Judicial perpetuation of values that the people are free to choose and have left behind has again and again been a source of difficulty for the courts. It is, in this context, a source of concern about hard look.

The other thing that might be said about State Farm is simply that, given the underlying politics, that particular holding may in fact represent the courts checking the President as much as it does the courts checking the agency.

DP [to the audience]: Now you get your chance.

QUESTION: I liave a question for Cass. I have to, first of all, agree. I don't like Heckler; I don't like Chevron; and I like State Farm. But I wonder how you can conclude that close judicial scrutiny inakes agencies put analysis first and conclusions second as opposed to conclusions first and more careful analysis that supports the conclusions later.

CS: That's a good question. The answer is, once you start to analyze a problem, then you start to think about it differently, often. This is soinething that sliould be studied empirically, but you can show actually that it has sometimes happened. One example is the airbags problein itself. When you know, as I know personally because I was there, when the Reagan Administration came in, passive restraints, anything having to do with that was top of the hit list-that is, on a literal hit list-and that was not an analyzed conclusion, that was an irrebuttable presumption. Now, once the courts said "that's out," it didn't happen that a better justification just came up, it was that the problem was revisited. I'd be very interested in seeing from the Elliott and Schuck study ${ }^{13}$ how often this liappens. What I do know, is that it happens sometimes, and in a way that really matters. I believe that something sinilar happened with

12. For an example of this approach, see K-Mart Corp. v. Cartier, Inc., $108 \mathrm{~S} . \mathrm{Ct} .1811,1817$ (1988) ("If the agency regulation is not in conflict with the plain language of the statute, a reviewing court must give deference to the agency's interpretation of the statute.").

13. Schuck \& Elliott, To the Chevron Station: An Empirical Study of Federal Administrative Law, 1990 DuKe L.J-(forthcoming June, 1990). 
regulation of lead; it was in the early days of the EPA. There was a decision made; Judge Leventhal sent it back; it turned out there was a very elementary error that was quite arguably politically driven, a very different result eventually came out. Even if that example is a little off, it liappens enough. Everyone can probably see it witl himself; it is not the case that once one is forced to analyze a problem, the conclusion comes first always; the fact that you have to do the analysis might make the conclusion softer or different.

DE: Just to answer that one question, in the data that I showed there, it shows that about $35-40 \%$ of the time, when a case is sent back to an agency, the agency really does reassess and make a major change. I think that's a good deal more than I expected before we did the study, but it leaves the question, is the glass half empty or half full? I think neither very simphistic view that agencies never rethink, are never affected, nor that they always respond to courts, is correct. It's someplace in between in the $35-40 \%$ range, but that's something. That does promote a major reevaluation. We also looked for factors other than the judicial review, that might explaim the turnaround and they really didn't exist. It seems to be that the second look-not the hard look but the second look-does in fact empirically, im a substantial but not a majority of cases, promote a real rethinking.

QUESTION: I'd like to think that rethinking is most likely when a court sends something back to an agency and says "You've gotten it wrong." I'm thinking more in terms of the systemic ex ante problem: knowing that the judicial review will occur, will that really change the conclusion of the agency?

DE: That's very hard to study.

PS: In my experience, the answer is yes, but that's old and limited experience.

QUESTION: This is addressed to everybody, but perhaps particularly Cass and Peter. Isn't it the case, or could it be the case, that hard look and increased presidential or pohitical controls are consistent, and that the latter, political controls, could be enhanced, perhaps thereby reducing the likelihood of reversals or the need for hard look?

CS: Yes. I am a real entlusiast for Executive Orders $12,291^{14}$ and $12,498^{15}$. Peter and I have written on that together, ${ }^{16}$ but I am not an enthusiast for the abandonment of the hard look doctrine. as a result. I

14. Exec. Order No. 12,291, 44 C.F.R. 1 (1988), reprinted in 5 U.S.C. $\S 601$ (1982).

15. Exec. Order No. 12,498, 50 Fed. Reg. 1036 (1985).

16. Strauss \& Sunstein, supra note 9. 
think they fit together beautifully and they are necessary correctives to the abuses of the other.

PS: If we can isolate for a moment the effect of hard look review on internal agency process from the effect of hard look review on the presidential process, and I'm not sure that that could be done, then I would prefer to see that impact on internal agency process disappear, or at least be subdued in comparison to what results from the presidential process. That is to say, if one has a President in fact supervising agency priorities-and it is just that process that makes me as enthusiastic as Cass is for [Executive Orders] 12,291 and 12,498 - then that aspect of hard look tends to make courts ask: "Did you get this exactly right?"

For example, in the air bags case, the court of appeals, in one of its early rulings, sends back a complex rulemaking because General Motors hadn't quite got the dummy's neck right. ${ }^{17}$ A court is just too prone to misunderstand the problem as it was before the agency and to lead to the kind of flyspecking that, on iny reading of the Mashaw and Harfst study of NHTSA administration, ${ }^{18}$ is indeed a principal part of their account of regulatory failure. So to the extent that one sees now in place a pretty decent presidential process for insisting that agencies have regulatory priorities and think about how much they're going to accomplish through this regulation rather than that regulation, I'm prepared to see the courts let go.

QUESTION: Comment on two of the three panelists. It seems to me that there's a lot of focus on what the agencies and the President want the policies to be at the agency and a bit of a slighting of what Congress wanted the policies to be. I was at the EPA during all the early 1970s, and was a colleague of Bill Pedersen and my experience was that it was cases such as the Kennecott case ${ }^{19}$ in 1972 that allowed lawyers in the EPA General Counsel's office to bring some element of Congress's legal controls to bear and time after time, what we saw when the packages came up from the program offices of the EPA was shoddy work, reflecting more of the attitude of the EPA engineers of what they wanted to do, and relatively hittle attention to rational-by "rational," I mean even good math-rulemaking, and certainly no attention to legal requirements. And it was Kennecott that gave us and a few other lawyers the ability to send the package back and say "We can't defend this. At least do it right and correct the math while you're at it."

17. Chrysler Corp. v. Department of Transp., 472 F.2d 659 (6th Cir. 1972).

18. Mashaw \& Harfst, Regulation and Legal Culture: The Case of Motor Vehicle Safety, 4 YALE J. ON REG. 257 (1987).

19. Kennecott Copper Corp. v. EPA, 462 F.2d 846 (D.C. Cir. 1972). 
CS: This is why I think that what I see as the conventional separation of powers analysis of Chevron is off. Chevron sees the opposition between court and agency and says that one ought to favor the agency because it's accountable. In a case in which the question is the meaning of a statutory term, I think you rightly point out that it is not court vs. agency, but Congress vs. agency, and this is why a certain form of the hard look doctrine can be a great friend of legahty, and of, I think, ordinary conceptions of the separation of powers.

DE: Well, I think the effect that you describe at EPA of strengthening the hand of the lawyers as opposed to the engineers or the programmatic people is probably in fact one of the effects that aggressive judicial review has. I wish I could find something to disagree with Peter Strauss about, because I normally like to disagree with Peter.

It's probably helpful that in my experience in the early period, in 1972, at EPA, I'm not at all convinced that environinental laws that are designed and run primarily by lawyers are a good thing. And I think that the over-judicialization of the regulatory process and the dominance of lawyers in policymaking positions within agencies, EPA in particular, is probably an illustration of the kind of thing that we would be better without, at least in the second generation. Picking up on the point about how these things change over time, maybe we needed some legalism in the early 1970s, but I think maybe now it's a different time, it's a different enterprise for the regulatory state and maybe there needs to be a change.

PS: If I can make what I think is the same point in a slightly different way, you did not face 12,291, and the kind of aggressive OMB oversight of agency fact-thinking processes that now occurs. Hal Bruff, sitting in the front row, has just published for the Adıninistrative Conference a fine study of that subject that will appear in George Washington Law Review ${ }^{20}$ soon. You should all read it; it is very much along the lines we've been talking about-that is, it recognizes the need for more controls of the President's control of the process. But I think one needs to go back to Kennecott and reexamine it in terms that now recognize siguificant political controls by the President and structural controls by the President. In some ways this is why I like Sierra Club v. Costle ${ }^{21}$ so much, and in part why I like Chevron: Chevron recognizes that courts are not alone in the business. The other reason why I like Chevron, and I've written at some length about this ${ }^{22}$ so I think I can say it very briefly, is

\footnotetext{
20. Bruff, Presidential Management of Agency Rulemaking, 57 GEO. WASH. L. REV. 533 (1989).

21. 657 F.2d 298 (D.C. Cir. 1981).

22. Strauss, One Hundred-fifty Cases Per Year: Some Implications of the Supreme Court's Limited Resources for Judicial Review of Agency Action, 87 ColuM. L. Rev. 1093 (1987).
} 
that we still have only one Supreme Court, and we have 168 court of appeals judges. If the notion is that any time a court of appeals looks at a complex statutory question, it gets it right and it gets it the same way that all the other court of appeals judges in this country are going to get it, and it gets it with a full understanding of the agency program and the way in which its reading of the statute will impact on that program, that is not a notion with which I can easily agree. That's not to say that there isn't a large role for the courts to pursue in enforcing legality. At the very least, at what is described as Chevron step 1, the courts are to ask what could the statute mean, and step in when the agency action stands outside of any possible meaning for the statute; and courts probably should look with the kind of cautionary regard that Cass also suggests for those cases in which what the agency is doing is plainly enlarging its own power. Nonetheless, a realistic look at what mode of control is going to produce cheap and effective governinent to the extent we want government here, won't always choose the courts.

QUESTION: If I could make just one follow-up about 12,291, I certainly don't know how it's working, inside the agencies, because I'm not there-it may be working rationally, technocratically, perfectly. But we did have 3171 - . . which extended until the day after the Carter administration took office on January 21, 1977. What that involved was very strong OMB control, supervision, bargaining with other agencies, and basically, in my opinion, and in the opinion of inost people at EPA, was very inuch political, it was not at all directed toward improving the performance [of the agencies] now 12,291 and all the other processes now are doing all those things, but one has to wonder if somebody couldn't press the question whether they are masks for a political process as well.

PS: Good question.

CS: When you think of 12,291, a lot of it is excellent. But keep in mind, this is President-Reagan's regulatory program, which has very deeply held political biases, soine of which I think are great, some of which are not so great. OMB control maybe helps technocracy, maybe not. OMB's focus, I assure you, and I know something about this, is not first and foremost on legality. And to the extent that it's not first and foremost on legality, Chevron is no help.

$\mathrm{DE}$ : Well, let me respond to [the question] of how we assess how good a job the courts are doing, you know, coinpared to what? When Peter says I wasn't there, that's right as far as the agency is concerned, but I was there as a law clerk on the D.C. Circuit in the mid '70s, when we 
decided cases like the Ethyl ${ }^{23}$ case and the Vermont Yankee ${ }^{24}$ case, and I can tell you that my perception is that the judges and law clerks did not really penetrate deeply into the facts and understand the consequences. In that sense I think Shep Melnick's book ${ }^{25}$ is really quite accurate and one of the pieces that Peter Schuck and I hope to do as an outgrowth of this study is to compare agency responses to reniands from courts as opposed to agency responses to the EPA science advisory board. The working hypothesis is that precisely because the EPA science advisory board, which is composed of a group of outside scientists, can penetrate more deeply and more credibly into the bad math that the people at the program office do, that agencies are much more likely to respond in a real way when that kind of credible reviewing institution questions their conclusions than when a court does.

Just one little story about that: in the Vermont Yankee case, and in the Baltimore Gas and Electric case, ${ }^{26}$ among other things, Judge Bazelon, for whom I was working, got the half life of plutonium wrong by a factor of 10. Now, this is a quite inessential element of the case, but you can imagine this going back to the scientists at the Nuclear Regulatory Commission and their saying, "This bozo doesn't even know what the half-hife of plutomum is." I don't have that data yet, at some point I'd like to have it, I think that looking at "leave agencies alone" or have hard look by courts and lawyers, is to create false oppositions in my view. I think that we need to be thinking in the future more creatively about what the right type of reviewing institutions are in various areas rather than just pushing courts, which were, after all, just around; a kind of bricolage process in which you take what's available and press it into service to perform a new function. If you sat down to design a reviewing institution for EPA, the D.C. Circuit is never what anyone would design. It just happened to be there, and you use it, and so on.

PS: I was at the NRC at precisely the time when Don was where he was. Perhaps all I'll say is that the impact of that Court of Appeals opinion on the Nuclear Regulatory Commission was to subtract, let's say roughly 10 man-years of effort from whatever else the Nuclear Regulatory Commission was able to do during the relevant period of time.

QUESTION: [There's one thing that I want to point out.] You have to include Congress's relationship with courts [which is] central to the

23. Ethyl Corp. v. EPA, 541 F.2d 1 (D.C. Cir. 1976), cert. denied, 426 U.S. 941 (1976).

24. Vermont Yankee Nuclear Power Corp. v. Natural Resources Defense Council, Inc., 547 F.2d 633 (D.C. Cir. 1976) rev'd, 435 U.S. 519 (1978).

25. R. MELNICK, supra note 4.

26. Natural Resources Defense Council v. NRC, 685 F.2d 459 (D.C. 1983), rev'd, 462 U.S. 87 (1983). 
courts' objectives. Now on to another point of the equation, I think the question to ask is how do you [consider the] impact of Congress's relationship with the executive branch. We now know [that] Congress is much more productive today than the executive branch. The Executive is behind. The theory now in which control lies [with the Executive]. I think it would be particularly useful to evaluate the errors of different courts and [think] about the methods that one uses for delegation.

PS: That's an excellent point, and is reflected in the kind of thing you've pointed out to ine in private discussions in the past; that, in fact the nature of what Congress is doing today is often extraordinarily precise delineation of what the agencies are expected to do rather than the broad delegations that may have characterized, say, the 1930s or even other periods of time when the presidency and the Congress were in the same political hands, and whether that is a product of what's expected from the agencies or what's expected from the courts is a nice issue. But clearly part of the pohtical control equation, and part of the legal control equation has also to look at the Congress and the inpact on that relationship.

DP: We are adjourned. 